\title{
An Investigation on the Current Situation of Learning Support Service of Network Teaching Platform
}

\author{
Hui Wang \\ Beijing City University \\ Beijing, China
}

\author{
Peng Zhang \\ Beijing City University \\ Beijing, China
}

\begin{abstract}
It has made the investigation from the perspective of learning support service. And it has investigated the learning support service of the network teaching platform of a university in Beijing from the aspects of resource support, emotional support, interactive support and management support. Through the analysis of the data, this paper argues that it should improve the learning support service of the network teaching platform from three aspects of software, hardware and guarantee mechanism. And it can promote students' autonomous learning with the full use of the network teaching platform.
\end{abstract}

Keywords-higher education; network teaching platform; learning support service

\section{INTRODUCTION}

The rapid development of Internet has promoted the transformation of educational mode. And the network teaching platform has gradually become an important part of students' learning in colleges and universities. The network teaching platform is a support platform for distance education based on Internet. It provides support tools for educators and learners to solve the problems in the teaching process such as teaching, learning, answering, discussion and homework. It supports share and interaction. And it assures the quality. Also, it is consistent with the standards of openness. It is necessary to carry out teaching support of modern distance education. The effective learning support service of network teaching platform will guide, help and promote students' autonomous learning. And it also can improve the quality and effect of distance learning.

\section{THE LEARNING SUPPORT SERVICES OF NETWORK TEACHING PLATFORM}

In 1993, Swift had made explanation of learning support services. "Student support is an organizational form through which learners can take full advantages of the teaching and learning facilities of the organization. The system has an interaction. And it can stimulate students' learning motivation" [1]. Ding Xingfu said: "Students can have learning in the network teaching platform. And the school teachers provide distance teaching for the students. This network teaching platform provides two-way interaction for teachers and students. It aims to guide, help and promote students' self-learning. And then, it may improve the quality and effectiveness of distance learning." [2]
This paper argues that learning support service is to help students to learn more effectively in pre-learning period, learning period and post-learning period. And it provides students with the sum of comprehensive learning services. In view of this, learning support services should include resource support services, emotional support services, management support services and interactive support services on the basis of network teaching platform.

\section{A. Resource Support Services}

Resource support services provide comprehensive resource supports for students. These supports are related to the improvement of resources and environment, the sharing of resources and the improvement of the communication form. It has the collection of learners' feedback on the utilization of resources [3].

\section{B. Emotional Support Services}

Due to the lack of the communication, the emotional support is to improve the distance education. And it can help students organize learning groups, build up learning communities, provide psychological counseling and summer campus, help learners solve various psychological and emotional problems, relieve mental stress, eliminate loneliness, and enhance self-confidence and so on [4].

\section{Management Support Services}

Management support services mainly aims to improve the online course management, personal network learning library, administrator network campus management, and online curriculum management.

\section{Interactive Support Services}

The interactive support service is to provide students with interactive support in the process of online learning. It aims to facilitate students to communicate with each other in the process of online learning. And it can avoid students' boredom. And it can establish learning community to have discussion. Also, they can supervise each other. Then, it can create good atmosphere of learning. 


\section{THE DESIGN AND IMPLEMENTATION OF SURVEY ON LEARNING SUPPORT SERVICE OF NETWORK TEACHING PLATFORM}

\section{A. The Contents of the Investigation}

With the literature review, the key points of the survey are divided into four modules in this paper: resource support, emotional support, management support and interactive support. With the different nature of the indicators, it has adopted the corresponding research methods. And then, it can ensure the rationality and reliability of the data. The specific details are shown in "Table I":

TABLE I. The RESEARCh CONTENT OF LEARNING SUPPORT SERVICES OF NETWORK TEACHING PlatFORM IN COLLEGES AND UNIVERSITIES

\begin{tabular}{|c|c|c|}
\hline Research Module & Focus & The Examination of the Indicators \\
\hline Resource Support & $\begin{array}{l}\text { Learning materials and extracurricular } \\
\text { extension, learning software, online class, } \\
\text { multimedia material and exercises }\end{array}$ & $\begin{array}{l}\text { The amount, richness and type of learning materials, the } \\
\text { degree of update, the convenient degree of search engine }\end{array}$ \\
\hline Emotional support & $\begin{array}{l}\text { To have the feedback of learning outcomes and } \\
\text { learning behavior timely }\end{array}$ & Feedback efficiency and feedback quality \\
\hline \multirow[t]{5}{*}{ Management support } & Curriclum Time and Sites and other notices & the situation of course announcement, the accuracy \\
\hline & Learning management & $\begin{array}{l}\text { Network autonomous learning schedule management, } \\
\text { autonomous curriculum management, performance } \\
\text { management, the practical management of resource } \\
\text { export }\end{array}$ \\
\hline & Homework management & To upload and submit homework \\
\hline & Curriculum management & $\begin{array}{l}\text { Elective course management, specialized course } \\
\text { management }\end{array}$ \\
\hline & User identity management and permissions & to set identity, to retrieve password \\
\hline \multirow[t]{2}{*}{ Interactive support } & Interactive tools & Interaction type and effect \\
\hline & Interactive process & $\begin{array}{l}\text { The fluency of the interaction process, the interaction } \\
\text { between teachers and students }\end{array}$ \\
\hline
\end{tabular}

\section{B. The Implementation of the Investigation}

The author had sample investigation of college undergraduates in December in 2016. And it investigated the status quo of learning support services of school network teaching platform. In this investigation, it made the selection of the effectiveness of the questionnaire according to the recovery. In the questionnaire, if it doesn't answer the status quo of the use of network teaching platform, the questionnaire would be useless. And if they have choices of multiple questions with single selection, the questionnaires would be useless.

In this investigation, there were 220 questionnaires. And it collected 205 questionnaires. The recovery rate was $93 \%$. The effective questionnaires were 200. And the effective rate was $91 \%$. The data were analyzed by SPSS data statistical analysis software.

\section{THE ANALYSIS OF THE INVESTIGATION OF LEARNING SuPPORT SERVICES OF NETWORK TEACHING PlATFORM}

The learning effect of learning support service of network teaching platform in colleges is mainly affected by four aspects: learner factors, teacher factors, network teaching platform factors, school factors and other factors.

\section{A. The Analysis of Learner Factors}

1) Gender and grade:In the survey, boys accounted for $55 \%$ of the total. And girls accounted for $45 \%$. Liberal arts students accounted for $40 \%$ of the total. And science students accounted for $46 \%$, art students accounted for $15 \%$. In terms of the needs and experiences of students' selfdirected learning in different grades, the samples are mainly junior and senior students. And they accounted for $68.5 \%$ of the respondents.
2) The utilization of the network teaching platform: In the process of investigating whether students have used the network teaching platform, $10.5 \%$ of the students haven't used the network teaching platform. In the investigation of the reasons why the students didn't use the network teaching platform, $52.4 \%$ of the students didn't use the platform without the teachers' requirements. And $28.6 \%$ of students believed that the structure of network teaching platform was single. And they have no interests in it.

3) The usage rate and time of the network teaching platform: $29.5 \%$ of the students have spent half an hour in the network teaching platform. $45 \%$ of the students have spent half an hour to an hour in the network teaching platform. And it has reached the total of $74.5 \%$. $44.5 \%$ of the students have used more than once a month. And it is almost half of the total. It can be seen that students don't spend much time in the network teaching platform. And it is mainly for the teachers' requirements to complete the practice or homework on the Internet. The attraction of the teaching platform for students is limited.

\section{B. The Analysis of Teacher Factors}

1) Teachers provide resource support in the network teaching platform: The learning support services of network teaching platform in colleges and universities are mainly composed of learning resources. The learning resources are various. And they can be divided into five types: multimedia material, stand-alone software, unit exercises, literature and syllabus. Teachers mainly provide multimedia material in the network teaching platform. And this type of resources accounted for $87 \%$ of the total. Most of the multimedia materials are teacher videos, online class and animation. On the one hand, the teachers are trying to improve the 
interesting of the network teaching platform. And it may improve students' interest in learning. On the other hand, it is the extension and supplement of extracurricular literature.

2) The types of resources help the students' learning in the largest degree: The types of resources which help the students' learning in the largest degree are multimedia material, the literature and stand-alone software. It seems that teachers provide students with more multimedia materials. And it also helps the students in the largest degree. And this matching rate is very high. Students think that unit exercises and syllabuses have a few supports to autonomic learning. The unit exercises are mainly the summary of each unit. And students tend to focus on the subject. It has exposed the students' learning psychology. And they just do it for the test. Teachers should guide students in this area. And they also should make multi-angle development of the resources. They can make further excavation in the current types of resources. Then the knowledge may coexist with the students' interest.

3) The matching rate of the resources provided by the teachers: The network teaching platform is an auxiliary tool for students to learn. And it should be matched with the learning of classroom. According to the survey, "to fit very well" accounted for 13\%, and "comparison match" accounted for $56 \%$. It can be seen that the matching degree of the network teaching platform in the course is only $69 \%$. It also needs the improvement.

4) The update rate of the resources provided by the teachers: $67 \%$ of the students believe that teachers rarely update the resources on the network teaching platform. And there is no change of the resources on the network teaching platform. It will add fresh learning materials once in a while. It can be seen that the teacher's participation isn't high. After the completion of the network teaching platform, it lacks certain incentive system. So, the resources on the network teaching platform are old. In the network teaching platform, there are only excellent classroom videos and knowledge of the textbooks. It can't mobilize the enthusiasm of the students.

\section{Analysis of the Factors of Network Teaching Platform}

The learning support service of the network teaching platform is mainly the management and support of the platform. As a new type of teaching, the network teaching platform is more focused on the platform design and the practical usage. It must establish the convenient and fast platform. It requires the managers to optimize the operability. And then, it can establish a high quality network teaching platform [5].

The network teaching platform provides many types of management support services for students. Usually, "student performance management" can reach to $100 \%$. Secondly, "course announcement" can account for 85\%. Students mainly have the course selection and class time and sites. Students have less understanding of "the resource management of platform" and "the exchange of management platform".

\section{Analysis of Other Factors}

In this study, it has investigated the status quo of emotional support services from the establishment of incentive mechanism, the establishment of interactive tools and the feelings in the process. According to the survey, $86 \%$ of students didn't receive the teachers' encouragement or appreciation in time. $14 \%$ of students can receive the teachers' encouragement. And it proves that the teachers' participation in the network teaching platform isn't high. In the process of using the platform, students often feel confused and bored. Students want the teachers to be able to participate in these activities. Combined with traditional learning, it should bring this kind of network learning into the classroom. In the classroom, they can develop the problems of the network resources. And the students can get encouragement and recognition timely.

In the network teaching platform, it also needs the communication between the teachers and the students and the communication among the students. And the interactive support services of network teaching platform can be used as the supplement. The students will not feel lonely in the autonomic learning [7].

With the establishment of the network teaching platform, the better interactive tools are BBS forum and teaching email. From online browsing experience, the establishment of these two functions isn't perfect. For example, "teaching email" will have fewer replies. And the methods of application aren't clear. Secondly, students need to have online discussion group and teach group, which is related to the emotional support. Students want to create a learning environment. When they encounter problems, they can make discussion with each other. "Private reminders" is the interactive tools that school hasn't yet established. And $42 \%$ of students want to experience this function.

The good interactive support services can't be separated from a variety of interactive tools. An important indicator of evaluating interactive support services is the use experience of these interactive tools. The advantages and disadvantages of interactive tools would affect students' learning experience. $33 \%$ of students feel easy to operate in the use of interactive functions of the network teaching platform. And they feel interactive exchange smooth. $67 \%$ of students feel that there is delay or inconvenient operation. Due to the design of the network teaching platform of the school, the managers need to keep upgrading. Due to the network problems, administrators need to improve network services to enhance the use experience of students.

\section{PROBLEMS AND SUGGESTIONS ON LEARNING} SUPPORT SERVICE OF NETWORK TEACHING PLATFORM IN COLLEGES AND UNIVERSITIES

\section{A. The Problems of Learning Support Services of the Network Teaching Platform}

- Resource support services: it is mainly the learning resources provided by the teachers. And the type of 
resources is still relatively traditional. Most of the resources are multimedia materials. The resource content is too old. The update is slow. The network classroom is relatively small. And they can't meet the needs of students.

- Management support services: the campus network configuration problems are the shortages of the management of school platform in the curriculum selection. It has caused the blockage. At the same time, the instability of the network has also affected the use experience of the students.

- Emotional support services: the teachers can't give the feedback to the students in the learning process timely. It should further improve learning community and the use experience. The current use of learning community isn't enough.

- Interactive support services: the schools have a few types of interactive tools. And it can't meet the current needs of interactive ways. The usage is low. It can't meet the needs of students on the mobile network. The usage is low. Secondly, there are still problems in the design of interactive tools, which leads to the blockage in the interaction process.

\section{B. Suggestions on the Development of Learning Support Service of Network Teaching Platform in Colleges and Universities}

1) It should strengthen the penetration of the network teaching platform, and pay attention to the use of network teaching platform: It should combine the network teaching platform with classroom teaching organically. Then, it can play the role of auxiliary teaching. Colleges and universities should organize the appropriate technical training, and establish effective technical support team. The teachers should change their traditional teaching concepts, and understand the learning in the network teaching platform. Then, it can combine the traditional teaching concepts with the network platform in the new area. It can fully integrate with the characteristics of network teaching platform for curriculum innovation. In the practice, it can sum up the experience and reform teaching model. It can strengthen the learning and use of the functions of the network teaching platform. It can make good use of the functions of the platform. And it can provide the students with teaching and learning services [10].

2) It can optimize the functional design of the network teaching platform to improve the practicality of services and the use experience of students: The network teaching platform of the schools should strengthen the management support services, and optimize the upgrade of module. The most important module is to find the learning material for the multimedia quickly. It should do a good job of search engine function within the websites. It can quickly and easily find the required learning content.

3) It should establish autonomic and high degree of learning support services of network learning platform with the mobile learning: So far, most of the colleges have established the network teaching platform successfully. However, it can't meet the needs of students and teachers. With the analysis of the demands, it needs to increase the necessary modules and functions. And then, the platform can play its diversification and personalization [9]. It can build mobile learning management system. So it can be applied to the current mobile devices. So it should use the development of mobile terminals reasonably. According to the characteristics of the mobile device and the contents of the platform, it should add some new interactive tools such as instant messaging. It will meet the needs of students. And then, the students can have learning in more convenient ways.

4) It should establish the normalized security mechanism: It can set up some clear rules for the teachers to develop the network courses. At the same time, it should establish incentive mechanism. It may encourage the enthusiasm of the teachers to develop online courses [11]. Schools should establish the update mechanism of standardized curriculum and reward mechanism to improve the teachers' attention to network courses and the updates of resources.

\section{CONCLUSION}

Colleges and universities should build relationships between the quality of online courses, excellent teaching outcomes and the evaluation of excellent teachers. It will not only increase the quality of network courses, but also promote teachers to think deeply about network teaching. In the end, it can improve the application of the network teaching platform and the quality of network teaching.

\section{REFERENCES}

[1] Wang Xiaomei, Ding Xin. Investigation and Research on Learning Support Services [J]. Open Education Research, 2005, 11.

[2] Wang Chunlian. Research on Design Mode of Network Education Learning Support Service System in Colleges and Universities [D]. Shandong: Qufu Normal University, 2006.

[3] Dong Zhaowei, Li Peixue, Li Wenjuan, etc. Research on the construction of new learning support service system in "Internet +" era [J]. Journal of Distance Education, 2015.

[4] Wang Man. Investigation and research on the status quo of learning support service of network teaching platform in colleges and universities [D]. Beijing: Capital Normal University, 2014.

[5] Wang Chunlian, Ma Xiufeng. Investigation and analysis of the status quo of network learning support service in colleges and universities [J]. Chinese audio-visual education, 2006, (7): 31-34.

[6] Wu Weining. The current situation and development countermeasure of network teaching platform in colleges and universities [J]. Value Engineering, 2010, 29 (31).

[7] Zhang Weiyuan. Analysis of the status quo and development of the network teaching platform in colleges and universities $[\mathrm{J}]$. Business, 2013, (5): 259.

[8] Wu Weining. Research on the current situation and countermeasures of learning support service in localization practice of MOOCs [D] Shanghai: Shanghai Ocean University, 2015. 
[9] Li Xiaoyan. Research on the current situation and development countermeasures of network teaching platform in colleges and universities [J]. Western Quality Education, 2016, 2 (13).

[10] Lv Huaxian. Research on the application of network teaching platform in colleges and universities-Taking Guilin university of technology as an example [J]. Market Forum, 2013, (10).

[11] Lv Li, Sun Hui, Zhao Jia, etc. The application and countermeasures of network teaching platform in colleges-Taking Nanchang Institute of Technology as an example [J]. Journal of Nanchang Institute of Technology, 2016, 35 (2). 